\title{
TINDAK TUTUR DAN PEMEROLEHAN PRAGMATIK PADA ANAK USIA DINI
}

\author{
Mohammad Siddiq \\ moh.siddiq@gmail.com
}

\author{
Universitas Ibnu Chaldun, Jakarta, Indonesia
}

\begin{abstract}
Abstrak
Manusia dilahirkan di dalam dunia sosial dimana mereka harus bergaul dengan manusia lain yang ada disekitarnya. Sejak awal hidupnya seorang individu sudah bergaul sosial dengan orang terdekat, meskipun bentuknya masih satu arah, seperti orang tua berbicara dan bayi hanya mendegarkan saja. Dalam perkembangan hidup selanjutnya, bahasa diperoleh sedikit demi sedikit. Pada saat yang sama individu tersebut dibawa ke dalam kehidupan sosial di mana terdapat rambu-rambu perilaku kehidupan. Sebagian dari norma-norma ini tertanam dalam bahasa sehingga kompetensi anak tidak hanya terbatas pada pemakaian bahasa (laguage usage) tetapi juga penggunaan bahasa (language use). Dengan kata lain, anak harus pula menguasai kemampuan pragmatik. Penelitian tindak tutur pada anak usia dini yang ditinjau dari aspek pragmatik ini berfokus pada aspek lokusi, ilokusi dan perlokusi, disamping itu melihat pula bagaimana pemerolehan pragmatik yang mencakup (1) perolehan niat komunikatif dan pengungkapan bahasanya, (2) pengembangan kemampuan bercakap dengan segala urutannya, dan (3) pengembangan piranti untuk membentuk wacana yang kohesif.
\end{abstract}

Kata kunci: Tindak Tutur, Perkembangan Pragmatik, Pemerolehan Bahasa, Anak Usia Dini.

Abstract

Humans are born in a social world where they have to get along with other humans around them. Since the beginning of his life an individual has socialized with the closest person, even though his form is still one-way, like parents talking and the baby is just listening. In later life developments, language is acquired little by little. At the same time these individuals are brought into social life where there are signs of life behavior. Some of these norms are embedded in language so that children's competence is not only limited to the use of language (laguage usage) but also the use of language (language use). In other words, children must also master pragmatic abilities. Speech action research in early childhood in terms of the aspects of pragmatics focuses on aspects of localization, illocutionary and perlocution, while also seeing how the acquisition of pragmatics includes (1) the acquisition of communicative intentions and language disclosure, (2) the development of the ability to speak in all its sequences, and (3) developing tools to form cohesive discourse.

Keywords: Speech Act, Pragmatic Development, Language Acquisition, Early Childhood

\section{PENDAHULUAN}

Dalam

kehidupan

di masyarakat manusia selalu melakukan interaksi atau hubungan dengan sesamanya. Dengan menggunakan bahasa. Bahasa dan manusia merupakan dua hal yang tidak dapat dipisahkan, dalam arti keduanya berhubungan erat. Bahasa merupakan alat komunikasi yang paling penting bagi manusia karena dengan bahasa manusia dapat mengekspresikan apa yang ada dalam pikiran atau gagasannya. Agar komunikasi dapat berlangsung dengan baik, manusia harus menguasai keterampilan berbahasa.

Keterampilan berbahasa meliputi empat macam, yaitu keterampilan menyimak, berbicara, membaca, dan menulis. Setiap keterampilan bahasa mempunyai 
hubungan yang erat dan konsep berpikir yang mendasari bahasa. Bahasa seseorang mencerminkan pikiran, semakin terampil seseorang berbahasa semakin cerah dan jelas pula pikirannya (Tarigan, 1986: 2). Bahasa adalah sistem lambang arbiter yang digunakan untuk bekerja sama, berinteraksi, atau mengidentifikasikan diri. Meningkatkan bahasa sebagai lambang makna dalam bahasa lisan lambang itu diwujudkan dalam bentuk tindak ujar dan dalam bahasa tulis wujud simbol tulisan dan keduanya memiliki tempat masing-masing. Baik bahasa lisan maupun tulisan digunakan manusia untuk berkomunikasi (Kridalaksana, 1984: 28).

Manusia dilahirkan di dalam dunia sosial dimana mereka harus bergaul dengan manusia lain yang ada disekitarnya. Sejak awal hidupnya seorang individu sudah bergaul sosial dengan orang terdekat, meskipun bentuknya masih satu arah, seperti orang tua berbicara dan bayi hanya mendengarkan saja. Dalam perkembangan hidup selanjutnya, bahasa diperoleh sedikit demi sedikit. Pada saat yang sama individu tersebut dibawa ke dalam kehidupan sosial di mana terdapat rambu-rambu perilaku kehidupan. Rambu rambu ini diperlukan karena meskipun manusia itu dilahirkan bebas, tetap saja harus hidup bermasyarakat. Ini berarti bahwa norma-norma sosial budaya yang berlaku dalam masyarakat tersebut perlu dikuasai. Sebagian dari norma-norma ini tertanam dalam bahasa sehingga kompetensi anak tidak hanya terbatas pada pemakaian bahasa (laguage usage) tetapi juga penggunaan bahasa (language use). Dengan kata lain, anak harus pula menguasai kemampuan pragmatik (Dardjowidjojo, 2000: 275).

Pada umumnya, penggunaan bahasa merupakan suatu keterampilan tidak dianggap sebagai sesuatu yang luar biasa rumit. Pemakaian bahasa terasa lumrah karena memang tanpa diajar oleh siapapun seorang bayi akan tumbuh bersamaan dengan pertumbuhan bahasanya. Dari umur satu sampai dengan satu setengah tahun seorang bayi mulai mengeluarkan bentuk-bentuk bahasa yang telah diidentifikasikan sebagai kata. Ujaran satu kata ini tumbuh menjadi ujaran dua kata dan akhirnya menjadi kalimat yang kompleks menjelang umur empat atau lima tahun. Setelah dewasa penggunaan bahasa seolah dilakukan tanpa berpikir. Ketika seseorang hendak mengungkapkan sesuatu pada saat itulah pula orang tersebut mengeluarkan bunyi-bunyi yang disebut bahasa.

Akan tetapi, bila direnungkan secara mendalam akan dirasakan bahwa pamakaian bahasa merupakan cerminan dari kemampuan yang hanya dimiliki oleh manusia. Sebagai contoh, pilihan kata "singa" yang diucapkan saat melihat seekor 
singa di kebun binatang menunjukkan bagaimana kompleksitas seseorang saat memilih kata yang berbunyi "singa" padahal dalam minda (mind) orang tersebut terdapat ribuan kata yang disimpan, sebagian mirip dan sebagian yang lain tidak mirip dengan kata atau konsep "singa". Misalnya kata harimau, gorila, kucing atau anjing yang mirip dengan konsep singa. Kemudian, kata singkong, singit, singkir, dan lainnya yang pelafalannya atau bunyinya mirip dengan kata singa. Sedangkan untuk kata yang tidak mirip misalnya pohon, gudeg, sepatu, sepeda dan lain sebagainya (Dardjowidjojo, 2012: 1-2). Bahkan, lebih jauh lagi, bahasa dapat menjadi cermin karakter bangsa. Ungkapan kepribadian seseorang yang perlu dikembangkan adalah ungkapan kepribadian yang baik, benar, dan santun sehingga mencerminkan budi pekerti yang baik (Wardhani, 2018: 1).

Pertanyaan yang menarik adalah bagaimana kata "singa" dan bukan kata lainnya yang dipilih oleh seseorang untuk digunakan dalam suatu proses komunikasi. Jika terjadi kekeliruan dalam berbicara (slip of the tongue), pilihan kata yang keluar pastilah tidak jauh dari kata yang ingin digunakan baik dilihat dari segi bunyi ataupun maknanya. Akan tetapi jika terjadi kekeliruan dalam pemilihan kata yang berkaitan dengan konsep tertentu atau terlepas dari kaidah yang telah ada, maka hal tersebut menarik untuk diteliti, khususnya pada kasuskasus berbahasa anak-anak usia dini dimana proses kebahasaannya sedang berkembang dengan pesat. Hal ini tentu akan menunjukkan bahwa dalam berbahasa seorang manusia melakukan aktivitas mental yang kemudian dituangkan dalam wujud bahasa yang digunakannya ketika berkomunikasi.

Kesalahan berbahasa dalam kaitannya dengan persoalan konsep pada anak usia dini menjadi sangat penting untuk mendapat perhatian karena bila konsep yang keliru tersebut terbawa hingga dewasa maka dapat mempengaruhi aktivitas komunikasi anak tersebut. Sebagai contoh tertukarnya kata "biru" yang merujuk pada konsep warna "hijau", atau "pulang" dengan "pergi", dan lain sebagainya. Kasus ini sebagaimana terjadi pada anak bernama Ameera yang berusia 3 tahun 7 bulan. Lebih jauh lagi, hal ini menjadi menarik, untuk melihat bagaimana pilihan-pilihan kata tersebut kemudian muncul dalam proses komunikasi sebagai ilokusioner dalam membentuk wacana yang kohesif.

Masalah dalam penelitian ini dapat dirumuskan dalam pertanyaan berikut ini: "Bagaimanakah tindak tutur dan pemerolehan pragmatik pada anak usia dini?" Berdasarkan pada 
rumusan masalah penelitian tersebut, maka dapat dikemukakan beberapa pertanyaan penelitian berikut: Bagaimanakah tindak tutur anak usia dini? Bagaimanakah lokusi, ilokusi dan perlokusi dalam tuturan anak usia dini? Bagaimana perolehan pragmatik pada anak usia dini? Bagaimanakah perolehan niat komunikatif dan pengungkapan bahasa anak usia dini? Bagaimanakah pengembangan kemampuan bercakap dengan segala urutannya? Bagaimanakah pengembangan piranti untuk membentuk wacana yang kohesif? (Ninio dan Snow, 1996: 11).

Ruang lingkup penelitian tindak tutur pada anak usia dini yang ditinjau dari aspek pragmatik ini dibatasi pada aspek lokusi, ilokusi dan perlokusi disamping itu melihat pula bagaimana pemerolehan pragmatik yang mencakup (1) perolehan niat komunikatif dan pengungkapan bahasanya, (2) pengembangan kemampuan bercakap dengan segala urutannya, dan (3) pengembangan piranti untuk membentuk wacana yang kohesif (Soenjono, 2000: 266).

Penelitian ini bertujuan untuk memperoleh pemahaman mengenai tindak tutur pada anak usia dini ditinjau dari aspek pragmatik. Penelitian ini merupakan penelitian studi kasus pada anak bernama Ameera yang berusia 3 tahun 7 bulan. Manfaat yang dapat diperoleh dari penelitian ini adalah, pertama, manfaat akademik, menambah khazanah ilmu pengetahuan yang berkaitan dengan kajian psikolinguistik, khususnya tentang tindak tutur pragmatik. Kedua, manfaat praktis, sebagai pemahaman terhadap perkembagian pragmatik dalam tindak tutur anak usia dini.

\section{KAJIAN TEORI}

Teori yang digunakan sebagai acuan dalam penelitian ini adalah teori tindak tutur yang mempertegas bahwa ungkapan suatu bahasa dapat dipahami dengan baik apabila dikaitkan dengan situasi konteks terjadinya ungkapan tersebut. Istilah tindak tutur muncul karena di dalam mengucapkan sesuatu penutur tidak semata-mata menyatakan tuturan tetapi dapat mengandung maksud dibalik tuturan itu. Istilah tindak tutur dalam bahasa Inggris dikenal dengan sebutan speech act. Tindak tutur dipahami sebagai: (1) perbuatan berbahasa yang dimungkinkan oleh dan diwujudkan sesuai dengan kaidahkaidah pemakaian unsur-unsur bahasa; (2) perbuatan menghasilkan bunyi bahasa secara beraturan sehingga menghasilkan ujaran bermakna; (3) seluruh komponen linguistik dan nonlinguistik yang meliputi suatu perbuatan bahasa yang utuh, yang menyangkut partisipan, bentuk penyampaian amanat, topik, dan 
konteks amanat itu; (4) pengujaran kalimat untuk menyatakan agar suatu maksud dari pembicara diketahui pendengar (Kridalaksana, 1984: 171).

Tindak tutur atau speech act merupakan suatu bentuk perbuatan berbahasa. Faktor-faktor linguistik dan non-linguistik sangat berpengaruh terhadap perbuatan berbahasa. Bagaimana kandungan makna atau informasi dalam bahasa tersebut disampaikan dan dipahami. Seringkali dijumpai tuturan yang tidak mengkomunikasikan informasi, tetapi mirip dengan perbuatan. Sebagai contoh, ketika seseorang mengatakan 'Saya minta maaf ...', 'Saya berjanji ...', 'Saya terima' (pada sebuah pernikahan), atau "Saya namakan kapal ini ...' ujaran-ujaran tersebut menyatakan realitas psikologis dan sosial yang baru.

The title of John Austin's famous book How To Do Things With Words conveys the essence of speech act theory. Austin (1962. p. 12) questions "an old assumption in philosophy" that to say something is to state something in a propositional sense. Sentences that convey referential information, in Austin's words, form locuionary acts. but many utterances do not describe or report anything. That is, they do not state anything and cannot be evaluated for their truth, but rather are iliocusiornary performances (DeLamater, 2003: 236).

Bagaimana sebuah informasi dalam suatu ujaran dapat dipahami dan mendapatkan respon akan berkaitan erat di antaranya dengan kompetensi semantik seseorang. Kompetensi semantik adalah kemampuan untuk melakukan dan memahami tindak tutur atau tindakan ilokusi.

Scarle (1974) says semantic competence is the ability to perform and understand speech acts or illocutionary acts. These acts are some of the many acts associated with a speaker's utterance in speech situations, speakers, hearers, and utterances (Walcott, 2007: 38).

Dalam peristiwa tindak tutur terjadi interaksi linguistik dalam satu bentuk ujaran atau lebih yang melibatkan dua pihak yaitu penutur dan lawan tutur dengan satu pokok tuturan di dalam waktu, tempat, dan situasi tertentu. Misalnya, interaksi yang berlangsung antara pedagang dan pembeli di pasar pada waktu tertentu dengan menggunakan bahasa sebagai alat komunikasinya.

Peristiwa tindak tutur merupakan dasar dari sebuah proses komunikasi yang dipadukan dengan prinsip bagaimana sebuah gagasan dalam pikiran diekspresikan melalui bahasa. Terdapat di dalamnya serangkaian 
hubungan analitis antara gagasan tindak tutur dengan apa yang hendak disampaikan penutur, perangkat lingustik yang diujarkan, apa yang pendengar mengerti dan aturan yang mengatur unsur-unsur linguistik tersebut.

the speech act is the basic unit of communication, taken together with the principle of expressibility, suggests that there are a series of analytic connections between the notion of speech acts, what the speaker means, what the sentence (or other linguistic element) uttered means, what the speaker intends, what the hearer understands, and what the rules governing the linguistic elements are (Searle, 1969: 22-24).

Secara pragmatis terdapat tiga jenis tindakan yang dapat diwujudkan oleh seorang penutur dalam suatu peristiwa tutur yakni tindak lokusi (locutionary act), tindak ilokusi (illocutionary act), dan tindak tutur perlokusi (perlocutionary act). Ketiga jenis tindakan ini yang kemudian menjadi fokus untuk ditemukan dalam subjek penelitian.

Tidak tutur lokusi adalah tindak tutur yang dimaksudkan untuk menyatakan sesuatu; tindak mengucapkan sesuatu dengan kata dan makna kalimat sesuai dengan makna kata itu di dalam kamus dan makna kalimat itu menurut kaidah sintaksisnya. Jadi, lokusi adalah tindak bertutur dengan kata, frasa, dan kalimat sesuai dengan makna yang dikandung oleh kata, frasa, dan kalimat itu. Contoh tindak tutur lokusi adalah ketika seseorang berkata "badan saya lelah sekali". Penutur tuturan ini tidak merujuk kepada maksud tertentu kepada mitra tutur. Tuturan ini bermakna bahwa si penutur sedang dalam keadaan lelah yang teramat sangat, tanpa bermaksud meminta untuk diperhatikan dengan cara misalnya dipijit oleh si mitra tutur. Penutur hanya mengungkapkan keadaannya yang tengah dialami saat itu. Contoh lain misalnya kalimat "Siddiq bermain gitar". Kalimat ini dituturkan semata-mata untuk menginformasikan sesuatu tanpa tendensi untuk melakukan sesuatu apalagi untuk memengaruhi lawan tuturnya.

Dewasa ini topik "Pragmatik" sangat dikenal dalam linguistik, padahal sebelumnya pragmatik lebih banyak diperlakukan sebagai sesuatu yang dapat dengan mudah dilupakan keberadaannya. Namun saat ini, disadari bahwa sifat bahasa dapat benar-benar dimengerti melalui studi mengenai pragmatik, yaitu bagaimana bahasa digunakan dalam komunikasi (Leech, 1993: 1). Disamping itu fungsi pragmatis adalah fungsi yang diacu oleh maksud tuturan di dalam pemakaiannya untuk berkomunikasi antar penutur (Faridah, 2017: 1). 
Pragmatik adalah studi tentang penggunaan bahasa dalam hubungannya dengan orang lain. Pragmatik bukan merupakan komponen keempat disamping fonologi, sintaksis, dan leksikon pada bahasa tetapi memberikan prespektif yang berbeda mengenai bahasa (Dardjowidjojo, 2012: 264265).

Dalam kenyataan, masalah perbedaan antara "bahasa" (langue) dengan "penggunaan bahasa" (parole) berpusat pada perselisihan antara semantik dengan pragmatik mengenai garis batas bidangbidang ini. Kedua bidang ini berurusan dengan makna, tetapi perbedaan di antara mereka terletak pada perbedan penggunan verba to mean (berarti):

[1] What does X mean? (Apa artinya $X$ ?)

[2] What did you mean by $X$ ? (apa maksudmu dengan $\mathrm{X}$ )

Lazimnya semantik memperlakukan makna sebagai suatu hubungan yang melibatkan dua segi (dyadic), seperti dalam [1], sedangkan pragmatik memperlakukan makna sebagai suatu hubungan yang melibatkan tiga segi (triadic), seperti dalam [2]. Dengan demikian dalam pragmatik makna diberi definisi dalam hubungannya dengan penutur atau pemakai bahasa sedangkan dalam semantik, makna didefinisikan semata-mata sebagai ciri-ciri ungkapan-ungkapan dalam suatu bahasa tertentu terpisah dari situasi, penutur dan petuturnya.
Sehingga secara garis besarnya, pragmatik dapat dipahami sebagai studi tentang makna dalam hubungannya dengan situasi-situasi ujar (speech situations) (Leech, 1993: 8).

Karena pragmatik merupakan bagian dari perilaku berbahasa maka penelitian mengenai pemerolehan bahasa perlu pula mengamati bagaimana anak mengembangkan kemampuan pragmatiknya. Nino dan Snow menyarankan pemerolehan pragmatik pada anak dapat dilakukan dengan mengamati: (a) pemerolehan niat komunikatif (communicative intens) dan pengembangan ungkapan bahasanya, (b) pengembangan kemampuan untuk bercakap-cakap dengan segala urutannya, dan (c) pengembangan piranti untuk membentuk wacana yang kohesif (Ninio dan Snow, 1996: 11).

Pemerolehan niat komunikatif. Niat komunikatif ditunjukkan anak pada mingguminggu awal setelah kelahirannya. Niat tersebut diekspresikan dengan tersenyum, menoleh bila dipanggil. Niat komunikatif secara vokalisasi, dalam bentuk bunyi baru dilakukan pada saat bayi berusia 13 bulan, setelah perkembangan biologisnya memungkinkan. Selain itu ucapan yang diucapkan adalah bentuk refleksi atas situasi yang menarik bagi dia yang dilisankan. Dari penelitian Ninio dan Snow didapati bahwa arah ujaran-ujaran awal adalah ke diri anak, artinya, semua 
ujaran yang dikeluarkan diarahkan untuk kepentingannya sendiri, bukan untuk orang lain. Karena itulah pada awal hidupnya anak kelihatan egois dan egosentris.

Pemerolehan Kemampuan Percakapan. Pada tahap ini anak mulai menguasai aturan-aturan percakapan. Anak memiliki kesantunan secara gradual dalam bergiliran ketika berkomunikasi. Percakapan mempunyai struktur yang terdiri dari tiga komponen, yaitu, (a) pembukaan, (b) giliran, dan (c) penutup. Secara naluri anak akan tahu kapan pembukaan percakapan itu terjadi. Bila orangtua menyapanya, itulah tanda bahwa percakapan akan dimulai. Begitu juga dari pihak anak; anak bisa memulai percakapan itu dengan menyapa atau melakukan sesuatu kepada orangtua, kakak, atau temannya.

Dari penelitian Pan dan Snow (1996) didapati bahwa pada umur 1,8 tahun anak hanya menanggapi sekitar 33\% dari apa yang ditanyakan oleh orangtuanya. Prosentase ini naik menjadi 56.7\% pada umur 2,5 - 3 tahun. Begitu pula relevansinya, hanya sekitar 19\% dari tanggapan anak yang relevan dengan topik yang sedang dibicarakan.

\section{Pemerolehan}

Piranti

Wacana. Anak belajar memperoleh piranti untuk membentuk wacana yang kohesif dalam bentuk percakapan baik orang dewasa sebagai teman berbicara atau dengan anak lain. Teman bicara orang dewasa sering kali membantu anak, dengan banyak mengulang kata kunci yang dianggap kurang didengar atau kurang dipahami anak. Percakapan seperti ini dapat berjalan cukup lancar karena interlokutor anak adalah orang-orang dekat yang umumnya memberikan dukungan dan yang dibicarakan adalah halhal yang dikenal anak. Berbeda dengan percakapan antar orang dewasa yang didasarkan pada asumsi akan adanya pengetahuan tertentu pada si interlokutor sehingga informasi sudah dapat dipilah-pilah menjadi mana yang lama dan mana yang baru sedangkan asumsi seperti itu belum dapat diterapkan pada anak (Ninio dan Snow, 1996: 268).

\section{METODE PENELITIAN}

Penelitian ini merupakan penelitian studi kasus yang menggunakan paradigma kualitatif deskriptif dengan pendekatan observasi alamiah (Naturalistic observation) dengan tambahan stimulus tertentu untuk memunculkan respon tertentu pula. Adapun teori yang dipakai dalam penelitian ini digunakan bukan dalam rangka menguji hipotesis (hypothesis testing), tetapi membangun hipotesis (hypotheses forming). Dalam hal ini, penelitian tidak didasarkan atas suatu hipotesis tertentu, melainkan atas beberapa persoalan dasar yang selanjutnya membentuk hipotesis. 
Hipotesis bentukan inilah yang selanjutnya digunakan dalam rangka menjawab tujuan penelitian (Brown dalam Davies dan Elder, 2004: 481-490)

Teknik pengumpulan data yang dipakai untuk menjaring data yang dibutuhkan adalah dengan teknik dokumentasi. Data primer yang digunakan berasal dari koleksi rekaman video kegiatan keluarga sehari-hari dan catatancatatan percakapan yang berlangsung secara natural yang dikumpulkan sejak awal kelahiran subjek penelitian pada tahun 2010 hingga awal tahun 2014. Piranti yang digunakan berupa kamera video Sanyo Xacti VP 100 dan kamera internal dari smartphone Blackberry.

Data yang diperoleh kemudian dianalisis secara deskriptif berdasarkan kategori pemerolehan pragmatik pada anak yang meliputi: (a) pemerolehan niat komunikatif (communicative intens) dan pengembangan ungkapan bahasanya, (b) pengembangan kemampuan untuk bercakap-cakap dengan segala urutannya, dan (c) pengembangan piranti untuk membentuk wacana yang kohesif.

\section{HASIL DAN PEMBAHASAN}

\section{Subjek dan Latar belakang Orang tua serta Lingkungan}

Subjek dalam penelitian ini adalah seorang anak perempuan bernama Ameera El Mawadda, yang sehari-hari dipanggil "Ameera". Dia dilahirkan dalam keadaan normal dengan proses persalinan yang normal pula, pada hari selasa tanggal 29 Juni 2010 atau 17 Rajab 1431 di Rumah Sakit Anak dan Bunda "Harapan Kita" sekitar pukul 03.00 dini hari. Berat badan sekitar 2,6 kg dengan panjang $49 \mathrm{~cm}$.

Ibunya bernama Julia Fasha yang biasa dipanggil dengan sebutan "Ibit" (sebutan untuk panggilan bagi anak kecil dalam bahasa aceh) merupakan perempuan kelahiran Jakarta 29 Juli 1980. Keluarga Julia merupakan keturunan Sumatera yang merantau ke pulau Jawa. Ibunya berasal dari daerah Pangkalan Susu, Brandan, Sumatera Utara sedangkan Ayahnya berasal dari Banda Aceh. Mereka bertemu dan menikah saat dalam perantauan. Pernah menetap di Cirebon dan Cepu serta New Zealand namun tidak lama untuk kepentingan tugas dinas dari Pertamina (Ayahnya bekerja di Pertamina) sampai akhirnya menetap di Jakarta sekitar tahun 1975.

Bahasa yang dipergunakan sehari-hari adalah bahasa Indonesia, sesekali bahasa Aceh digunakan hanya antara Ayah dan Ibunya Julia dan beberapa keluarga yang usianya se-level dengan Ayah dan Ibunya, seperti om dan tante yang sedang berkunjung atau dalam suatu acara keluarga. Akan tetapi, jarang sekali terlihat 
komunikasi dengan menggunakan bahasa Aceh, di antara kalangan usia muda se-level Julia atau antara orangtua dengan anak mudanya. Mungkin hal tersebut adalah salah satu faktor yang membuat Julia dan ketiga saudarinya yang lain tidak terlalu lancar dalam menggunakan bahasa Aceh. Namun saat terjadi proses komunikasi dalam bahasa Aceh, misalnya saat acara keluarga, mereka dapat mengerti pesan atau kandungan maknanya sehingga Julia dan ketiga saudarinya dapat disebut sebagai pengguna bahasa Aceh secara pasif.

Julia dibesarkan di lingkungan daerah Jakarta golongan kelas menengah ke atas. Persentuhannya dengan dialek Betawi tidak terlalu kental karena seringkali berada dalam lingkungan yang cukup heterogen. Pendidikan yang diperolehnya sejak TK, SD, SMP, SMA dan Universitas dilaluinya di Jakarta pula. Pada saat SMP ia sempat mengenyam pendidikan pesantren di Pondok Pesantren Darunnajah selama tiga tahun, sehingga ia sempat menggunakan bahasa Inggris dan Arab (penggunaan kedua bahasa tersebut wajib di lingkungan pondok) baik secara aktif maupun pasif. Lingkungan pesantren yang santri-santrinya berasal dari berbagai pelosok wilayah Indonesia memberikan pengalaman dan pengetahuan tentang bermacam dialek yang ada di nusantara. Setelah lulus SMA, Julia melanjutkan studi di Universitas Negeri Jakarta pada jurusan Pendidikan Bahasa dan Sastra Arab hingga selesai di tahun 2002 dan kemudian menikah di tahun 2003.

Ayah Ameera, Mohammad Siddiq, merupakan seorang pria kelahiran Jakarta 1 Desember 1980. Memiliki ayah yang kelahiran Jepara, Jawa Tengah dengan bahasa ibu bahasa Jawa. Sedangkan Ibunya adalah seorang perempuan kelahiran Selayar, Sulawesi Selatan dengan bahasa pertamanya bahasa MakassarSelayar. Siddiq lahir di lingkungan keluarga yang akrab dengan dunia pendidikan Islam khususnya pesantren. Ayahnya berasal dari kalangan ulama di desa Bangsri, Jepara. Ia merupakan lulusan pesantren yang terletak di Lasem daerah perbatasan Jawa Tengah dengan Jawa Timur yang kemudian merantau ke Mekkah, kemudian menyelesaikan sarjananya di Libya dan pascasarjananya di Marocco, bahkan sempat aktif menjadi guru dan dosen di Marocco. Sepulangnya dari Marocco ayahnya berkeluarga, bermukim di Jakarta dan bertugas di Departemen Agama sambil mengajar di Universitas Ibnu Chaldun Jakarta, sempat pula mengajar di jurusan Bahasa dan Sastra Arab Universitas Indonesia serta di Lemhanas. Selama bertugas di Departemen Agama hingga pensiunnya di tahun 2002, ayahnya setiap tahun berangkat ke Arab Saudi sebagai petugas haji. 
Sempat pula menjabat sebagai Kepala Bidang Urusan Haji di Jeddah yang menurut sertakan keluarganya untuk bermukim di sana selama kurang lebih 4 tahun.

Sedangkan Ibunya, lahir dari keluarga pebisnis yang juga aktivis Muhammadiyah Sulawesi Selatan. Ia merupakan alumni Pondok Pesantren Diniyah Putri Padang Panjang di Sumatera Barat, sebelum akhirnya kembali ke Sulawesi untuk menikah lalu merantau dan bermukim di Jakarta. Latarbelakang kedua orangtuanya ini mempengaruhi Siddiq kecil, untuk akrab dengan bahasa Arab yang biasanya digunakan saat mempelajari Al Qur'an di rumah selain di Madrasah Ibtida'iyah pada waktu sore hari seusai sekolah dari SD. Disamping itu, karena terdapat dua budaya yaitu Jawa dan Sulawesi, nampaknya bahasa Indonesia menjadi pilihan utama yang dominan digunakan dalam komunikasi antar keluarga. Siddiq juga mendapatkan pendidikan pesantren di Darunnajah Jakarta yang mewajibkan penggunaan bahasa Arab dan Inggris dalam komunikasi sehari-hari. Kemudian dilanjutkan dengan berkuliah di jurusan bahasa Arab di Universitas Negeri Jakarta.

Berdasarkan latarbelakang orangtua dan keluarga tersebut dapat dilihat bahwa terjadi persentuhan berbagai bahasa diantaranya Bahasa Jepara - Jawa Tengah, Aceh - Melayu - Sumatera Utara, Selayar - Makassar -
Sulawesi Selatan, Indonesia, Arab, Inggris, Padang, Jakarta dan lainnya. Latarbelakang ini yang kemudian berpengaruh dalam membentuk situasi kebahasaan pada lingkungan Ameera. Dimana bahasa Indonesia menjadi bahasa yang dominan dan merupakan pilihan utama yang digunakan dalam komunikasi sehari-hari di lingkungan keluarga.

Selain kedua orangtuanya, dalam keluarga itu ada pula asisten rumah tangga. Ada yang dari daerah Jawa dan Sunda. Selain itu, adapula tetangga yang berasal dari Sunda, Betawi, Batak dan keturunan Cina. Ameera pun seringkali berinteraksi dengan lingkungan komunitas Sekolah Alam, dan keluarga yang berbeda domisili dengan ragam bahasa dan dialek yang berbeda. Dengan demikian, interlokutor atau pemberi masukan (input) pada Ameera tidak hanya dari orangtuanya saja namun dari lingkungan yang sifatnya heterogen dengan menggunakan bahasa Indonesia ragam informal.

Ameera tumbuh dalam keluarga yang termasuk kelas menengah yang untuk kebutuhan sehari-hari maupun kebutuhan primer yang lain dapat tercukupi. Di samping mainan seperti boneka atau yang lain, orangtua Ameera (termasuk keluarga dan kerabat lainnya) banyak memberikan buku anak-anak, termasuk buku tentang objek, buku mengenal huruf, buku tentang angka, buku cerita, buku 
gambar beserta alat gambarnya.

Pemberian tersebut merupakan perbuatan naluri dan bukan disengaja untuk kepentingan penelitian. Kebanyakan buku-buku yang ada termasuk jenis ensiklopedia seperti seri How Things Works, seri penemupenemu dunia, seri tentang anggota tubuh manusia, cerita-cerita dari pustaka lebah, kisah nabi Muhammad, kisah para sahabat Rasulullah, dan lain-lain. Ameera menyukai buku-buku, terutama buku-buku yang memuat beraneka gambar dan warna.

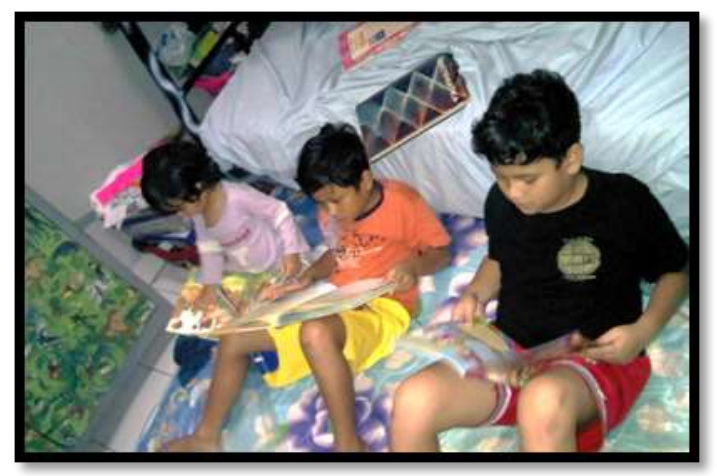

Gambar 1 Ameera Membaca Buku bersama Kakak-kakak

Setiap malam menjelang tidur diantara kegiatan yang dilakukan adalah orangtua membacakan buku kepada anakanak, baik buku-buku fiksi maupun kisah-kisah yang diangkat dari kehidupan nyata. Setelah dibacakan buku, biasanya orangtua memberikan pertanyaanpertanyaan seputar pandangan atau pikiran dan apa yang anak-anak mengerti dari bacaan yang telah dibaca, selain itu, hal tersebut memberikan kesempatan kepada mereka untuk mengungkapkan pikiran-pikiran mereka. Namun dalam kegiatan ini, partisipasi Ameera belum cukup tampak, lebih pada menyimak dan memberikan komentar sekedarnya saja.

Selain tersedianya bukubuku, tersedia pula video dan games baik dalam bahasa Indonesia maupun Inggris. Pada saat Ameera berusia 1 s.d. 2 tahun, video dan game yang tersedia di rumah, termasuk film-film kartun di saluran Disney Junior serta Baby First TV hampir semuanya berbahasa Inggris. Sehingga sering kali, pada waktu itu ujaran-ujaran yang muncul adalah kata-kata dalam bahasa Inggris, seperti yes, oh no, open, let's go, dan sebagainya.

Ameera termasuk anak yang riang, ramah, kepribadiannya terbuka, dan dapat bergaul dengan orang dewasa maupun sesama anak. Di rumah ada dua orang anak pembantu yang sering bermain bersama Ameera dan kakakkakaknya. Biasanya mereka datang di siang hari dan pulang di sore hari, karena ibu mereka membantu pekerjaan rumah tangga hanya separuh hari. Yang menarik adalah salah satu dari mereka, bernama Naila yang berusia sekitar 5 tahun adalah anak yang tunarungu dan tunawicara. Saat bermain bersama Ameera, komunikasi dapat terjadi meskipun tidak selancar dengan anak yang normal.

Ameera dan ketiga saudaranya adalah anak-anak yang mengikuti program Home 
Schooling, meskipun tergabung dalam Komunitas Sekolah Alam Tangerang, Klub Oase Rumah Inspirasi, Gymnastik, dan lainnya, Interkulator yang sangat intensif frequensi komunikasinya adalah kedua kakaknya bernama Adam yang berusia 9 tahun 8 bulan dan Ibrahim yang berusia 7 tahun 9 bulan serta adiknya yang berusia 11 bulan.

Bahasa Ibu (motherese) yang dipakai dalam keluarga Ameera adalah bahasa Indonesia ragam informal. Meskipun lahir, besar dan tinggal di daerah Jakarta yang identik dengan bahasa Betawi, kedua orangtua Ameera berasal dari keluarga yang bukan penutur Betawi asli sehingga ragam bahasa Indonesia informal yang dimaksud di sini adalah ragam yang kebanyakan dipakai oleh orang yang tinggal di Jakarta minus dialek Betawinya.

Sebagaimana diketahui bahwa latarbelakang orang tua Ameera maupun lingkungannya bersifat multikultural, akan tetapi pengaruh bahasa daerah, maupun bahasa asing boleh dikatakan tidak terlalu besar. Dan secara umum, bahasa yang dipakai dalam interaksi Ameera dalam keluarga maupun lingkungan sekitar, secara bervariasi lebih didominasi oleh bahasa Indonesia ragam informal dan formal. Misalnya saja, pada lingkungan masyarakat sekitar, untuk orang pertama menggunakan kata "aye" atau "gue", sedangkan di rumah yang digunakan adalah kata "aku". Kemudian penggunaan "dong", "sih", masih terlihat dalam percakapan sehari-hari.

Pada bagian selanjutnya akan dibahas mengenai tindak tutur yang meliputi aspek lokusi, ilokusi dan perlokusi serta kategorisasi tindak tutur pada Ameera. Setelah itu akan dibahas pula mengenai pemerolehan pragmatik Ameera yang meliputi (1) pemerolehan niat komunikatif dan pengungkapan bahasa; (2) pemerolehan kemampuan percakapan; (3) pemerolehan piranti wacana dengan juga melihat aspek lokusi, ilokusi dan perlokusi (tindak tutur).

\section{Tindak Tutur Lokusi, Ilokusi, dan Perlokusi}

Peristiwa tindak tutur merupakan dasar dari sebuah proses komunikasi yang dipadukan dengan prinsip bagaimana sebuah gagasan dalam pikiran diekspresikan melalui bahasa. Terdapat di dalamnya serangkaian hubungan analitis antara gagasan tindak tutur dengan apa yang hendak disampaikan penutur, perangkat lingustik yang diujarkan, apa yang pendengar mengerti dan aturan yang mengatur unsur-unsur linguistik tersebut. Secara pragmatis terdapat tiga jenis tindakan yang dapat diwujudkan oleh seorang penutur dalam suatu peristiwa tutur yakni tindak lokusi (locutionary act), tindak ilokusi (illocutionary act), dan tindak tutur perlokusi (perlocutionary act). 
Tindak lokusi adalah tindak tutur yang berhubungan dengan mengatakan sesuatu. Kalimat dituturkan semata-mata untuk menginformasikan sesuatu tanpa tendensi untuk melakukan sesuatu apalagi untuk memengaruhi lawan tuturnya. Pada Ameera tindak lokusi dapat dilihat pada saat Ameera sedang bermain sambil bernyanyi.

Ameera

$$
\begin{aligned}
& \text { atu tenang belajar } \\
& \text { bersama ibu u, dimana } \\
& \text { taja 'aku senang belajar } \\
& \text { bersama ibuku, dimana } \\
& \text { saja' (Hasil observasi, } 8 \\
& \text { April 2014). }
\end{aligned}
$$

Kejadian lain adalah saat ayahnya Ameera sedang berada di studio, Ameera datang menghampiri sambil memeluk sang Ayah dan mengungkapkan bahwa ia menyayangi ayahnya.

$\begin{aligned} & \text { Ameera : } \text { Bibi, atu tayang bibi } \\ & \text { [Abi, aku sayang Abi] } \\ & \text { Bapak bapak jelek a } \\ & \text { boleh cium amina, bibi } \\ & \text { boleh, bunda boleh, ba } \\ & \text { adam boleh, baim boleh, } \\ & \text { musa boleh 'bapak-bapak } \\ & \text { yang jelek tidak boleh } \\ & \text { cium Ameera, (kalau) } \\ & \text { Abi boleh, Bunda boleh, } \\ & \text { bang Adam boleh, } \\ & \text { Ibrahim boleh, Musa } \\ & \text { boleh' (Hasil observasi, } \\ & \text { 8 April 2014). }\end{aligned}$

Selanjutnya, ilokusi dipahami sebagai suatu tindak tutur yang mengandung maksud dan fungsi atau daya tuturan. Tindak ilokusi Ameera dapat dilihat pada percakapan berikut:

\footnotetext{
Ameera : Bibi ga pake baju 'Abi tidak pakai baju'

Ngapain ga pake baju?
}

'mengapa tidak pakai baju?'

Pake bajuu '(ayo) pakai baju' (Hasil observasi, 8 April 2014).

Kalimat Ngapain ga pake baju? 'mengapa tidak pakai baju?' dapat dipahami sebagai sebuah kalimat pertanyaan, akan tetapi sesungguhnya kalimat tersebut menjadi ilokusi yang mengandung makna "ayo pakai baju". Hal tersebut kemudian menjadi lebih jelas lagi ketika Ameera mengucapkan Pake bajuu '(ayo) pakai baju'.

Pada kesempatan lain, terjadi perbincangan saat makan bersama, saat itu ada ayah Ameera

\begin{tabular}{|c|c|c|}
\hline Ameera & : & $\begin{array}{l}\text { Bibi, makan pake tendok } \\
\text { 'Abi, makan pakai sendok' }\end{array}$ \\
\hline Ibrahim & : & $\begin{array}{l}\text { Terserah bibi Ameera, mau } \\
\text { makan pake sendok atau } \\
\text { enggak }\end{array}$ \\
\hline Abi & : & $\begin{array}{l}\text { Bibi makan pakai tangan, } \\
\text { Ameera makan pakai } \\
\text { sendok (Hasil observasi, } 8 \\
\text { April 2014). }\end{array}$ \\
\hline
\end{tabular}
dan kakaknya yang bernama Ibrahim. Ameera melihat ayahnya makan menggunakan tangan, dan ia meminta agar ayahnya makan menggunakan sendok.

Kalimat "Bibi, makan pake tendok" 'Abi, makan pakai sendok' dapat dipahami sebagai sebuah kalimat informasi, bahwa jika seseorang makan maka ia perlu menggunakan sendok. Kalimat tersebut kemudian mengandung maksud ilokusi agar ayahnya Ameera makan dengan menggunakan sendok. 
Tindak perlokusi adalah sebuah tuturan yang dituturkan oleh seseorang seringkali mempunyai daya pengaruh atau efek bagi yang mendengarkan. Pada Ameera tindak perlokusi dapat dilihat pada percakapan yang terjadi saat Ameera bermain balok bersama bundanya, saat itu usia Ameera 3 tahun 6 hari.

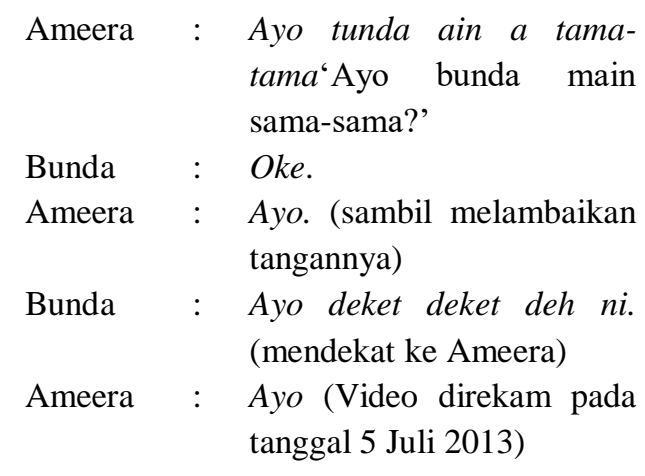

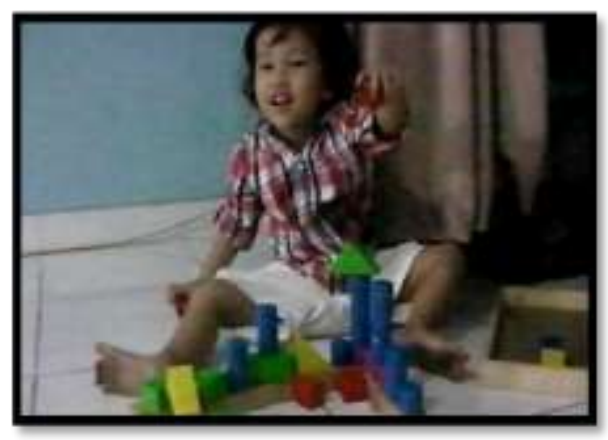

Gambar 2. Ameera bermain balok Konsep mengenai tindak tutur (Speech Acts) mulai dipikirkan oleh guru besar Universitas Oxford, John. L. Austin, pada ceramahnya di Universitas Harvard tahun 1955. Ceramah ini kemudian diterbitkan menjadi buku dengan judul How to Do Things with Words pada tahun 1962 setelah ia meninggal. Karyanya kemudian dilanjutkan oleh salah seorang mahasiswanya J. R. Searle, yang kemudian menerbitkan buku Speech Act 282 | Jurnal Kredo Vol. 2 No. 2 April 2019
(1969). Searle membagi tindak tutur ke dalam lima kategori. Kelima jenis itu adalah tindak tutur representatif, direktif, ekspresif, komisif, dan deklarasi (Dardjowidjojo, 2012: 94-95).

Tindak tutur representatif merupakan tindak tutur yang mengikat penuturnya kepada kebenaran atas hal yang dikatakannya.Tindak tutur representatif Ameera muncul, misalnya saja saat Ameera selesai mandi yang melaporkan dirinya yang baru saja selesai mandi kepada ayahnya.

$$
\begin{aligned}
\text { Ameera : } & \text { Bibi, atu udah mandi, } \\
& \text { atu udah wangi 'Abi } \\
& \text { aku sudah mandi, aku } \\
& \text { sudah wangi'. }
\end{aligned}
$$

Tindak tutur direktif adalah tindak tutur yang dimaksudkan penuturnya agar mitra tutur melakukan tindakan sesuai apa yang disebutkan di dalam tuturannya. Tindak tutur direktif Ameera muncul pada kalimat berikut:

Ameera : Bibi, atu udah mandi, atu udah wangi 'Abi aku sudah mandi, aku sudah wangi'. Ini tium! 'ini cium' (sambil menyodorkan ketiaknya ke ayahnya).

Kalimat Ini tium! 'ini cium' (sambil menyodorkan ketiaknya ke ayahnya) merupakan kalimat perintah yang muncul setelah Ameera memberikan informasi tentang dirinya yang baru saja selesai mandi, ia memerintahkan agar ayahnya mencium harum tubuhnya setelah ia mandi. 
Tindak tutur ekspresif

adalah tindak tutur yang dimaksudkan penuturnya agar tuturannya diartikan sebagai evaluasi tentang hal yang disebutkan dalam tuturan itu, misalnya tuturan mengucapkan terima kasih, mengucapkan selamat, menyanjung, memuji, dan sebagainya. Tindak tutur ekspresif Ameera dapat dilihat saat ia mengungkapkan rasa sayangnya kepada ayahnya.

Ameera : Bibi, atu tayang bibi

'Abi, aku sayang Abi'

Kalimat "Bibi, atu tayang bibi' 'Abi, aku sayang Abi' merupakan kalimat yang mengekspresikan perasaan Ameera terhadap ayahnya. Tidak hanya itu tuturan Ameera juga diiringi dengan tindakan memeluk dan mencium ayahnya.

Tindak tutur komisif adalah tindak tutur yang mengikat penuturnya untuk melaksanakan segala hal yang disebutkan dalam ujarannya, misalnya berjanji, menyatakan kesanggupan dan lain sebagainya. Tindak tutur komisif Ameera muncul diantaranya saat Ameera belajar untuk bersih-bersih sendiri di kamar mandi (toilet training).

Ameera : $\begin{aligned} & \text { Bibi, atu a tebok sendiri 'Abi, } \\ & \text { aku mau cebok sendiri' }\end{aligned}$
Abi $\quad$ Ameera bisa cebok sendiri?
Ameera : Bita 'bisa'
Tindak tutur deklarasi
merupakan tindak tutur yang
dimaksudkan penuturnya untuk
menciptakan hal (status, keadaan,

dan sebagainya) yang baru. Tindak tutur deklarasi Ameera misalnya muncul pada kalimat berikut:

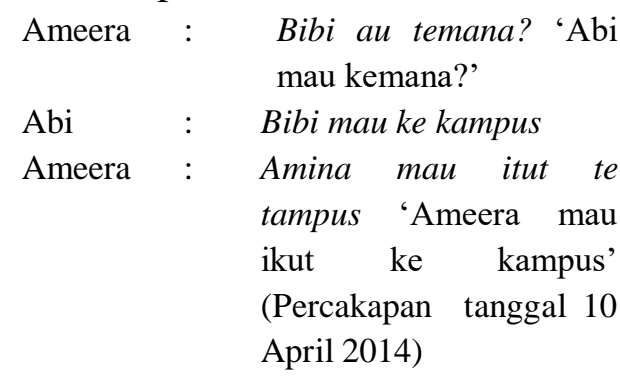

Kalimat "Amina mau itut te tampus" muncul saat ayahnya sedang bersiap untuk berangkat ke kampus. Melihat hal tersebut Ameera kemudian memutuskan untuk ikut bersama ayahnya.

\section{Pemerolehan Pragmatik}

Pragmatik adalah studi tentang penggunaan bahasa dalam hubungannya dengan orang lain. Pragmatik bukan merupakan komponen keempat disamping fonologi, sintaksis, dan leksikon pada bahasa tetapi memberikan prespektif yang berbeda mengenai bahasa (Dardjowidjojo, 2012: 264265).

Dalam kenyataan, masalah perbedaan antara "bahasa" (langue) dengan "penggunaan bahasa" (parole) berpusat pada perselisihan antara semantik dengan pragmatik mengenai garis batas bidangbidang ini. Kedua bidang ini berurusan dengan makna, tetapi perbedaan di antara mereka terletak pada perbedaan penggunaan verba to mean (berarti):

[1] What does X mean? (Apa artinya $X$ ?) 
[2] What did you mean by $X$ ? (apa maksudmu dengan $\mathrm{X}$ ) Nino dan Snow (1996) menyarankan pemerolehan pragmatik pada anak dapat dilakukan dengan mengamati: (1) pemerolehan niat komunikatif (communicative intens) dan pengembangan ungkapan bahasanya, (2) pengembangan kemampuan untuk bercakap-cakap dengan segala urutannya, dan (3) pengembangan piranti untuk membentuk wacana yang kohesif. Berikut ini akan disajikan mengenai pemerolehan pragmatik pada Ameera berdasarkan ketiga komponen tersebut dengan juga melihat aspek lokusi, ilokusi dan perlokusi (tindak tutur).

\section{Pemerolehan Niat Komunikatif dan Pengungkapan Bahasa}

Komunikasi non-verbal pada anak sebelum anak dapat mengeluarkan bentuk yang bermakna sebenarnya merupakan kemampuan pragmatik anak. Mereka mengatakan bahwa anak sebenarnya sudah tahu mengenai esensi penggunaan bahasa pada waktu anak berumur beberapa minggu. Kent dan Miolo bahkan mengatakan bahwa janin pun sebenarnya telah terekspos pada bahasa manusia melalui lingkungan intrauterin. Hal ini kemudian tampak dari kesukaan anak pada suara ibunya daripada suara orang lain. Perbedaan antara orang dewasa dengan bayi hanyalah bahwa bayi menanggapi ujaran orang dewasa belum secara verbal (Dardjowidjojo, 2012: 276).

Senyum, tawa, tangis, dan teriakan kecil semuanya merupakan piranti pragmatik yang digunakan anak. Demikian pula kenyataannya bahwa pada umur 11 bulan, Ameera telah dapat merespon panggilan namanya dengan senyuman dan teriakan kecil sambil mengulurkan tangan seperti sedang menawarkan benda yang ada ditangannya, menunjukkan telah adanya kemampuan pragmatik sejak dini (video tanggal 30 Mei 2011).

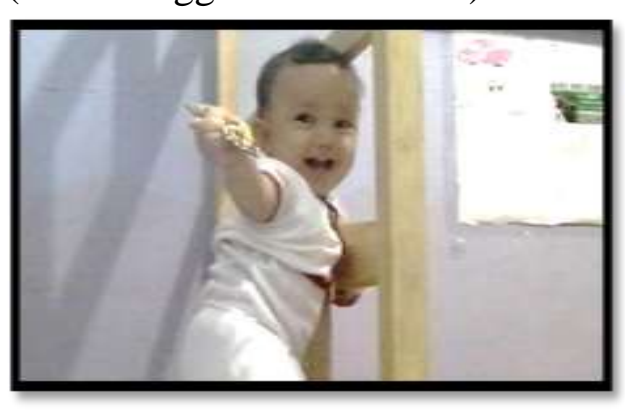

Gambar 3. Ameera usia 11 bulan

Salah satu bentuk yang umum dipelajari orang dalam mengkaji kemampuan pragmatik anak adalah dengan menganalisis percakapan yang dibuat oleh anak dengan orang dewasa atau anak lain. Pengungkapan bahasa secara verbal berupa kata pada Ameera telah nampak pada saat Ameera berusia 1,5 tahun. Ujaran yang disebut oleh Dore sebagai Primitive Speech Act (PSA) seperti labeling, repeating, answering, requesting action, requesting answer, calling, greeting, protesting dan practicing muncul dalam bentuk yang sangat sederhana. Sebagai contoh, Ameera 
senang sekali mengucapkan kata "No" [Tidak] (dalam bahasa Inggris). Tujuan ilokusioner dari tindak ujaran tersebut bisa jadi termasuk dalam salah satu berbagai kemungkinan seperti:

(a) Pernyataan (labeling): "No" 'Tidak', saat Ameera menolak untuk mandi.

(b) Perintah (requesting action): "No" 'Tidak', saat Ameera tidak mau benda A tetapi memilih benda B.

(c) Pengulangan (repeating) dan Latihan (practicing): "No" 'Tidak', Ameera hanya melakukan pengulangan kata "No" pada setiap pertanyaan yang diajukan.

(d) Protes (protesting): "No" 'Tidak', saat Ameera tidak setuju terhadap perbuatan kakaknya.

Begitupula dengan kata "Nda" 'Bunda' yang seringkali muncul saat Ameera berusia 1 s.d. 1,5 tahun, tujuan ilokusioner dari tindak ujaran tersebut bisa jadi termasuk dalam salah satu berbagai kemungkinan seperti digunakan untuk memanggil bundanya (calling) atau bentuk lain dari kebutuhannya untuk mendapatkan respon (requesting answer), atau sebagai sapaan (greeting) saat melihat bundanya datang menghampiri.

Perolehan pragmatik anak sebenarnya sudah dimulai sangat awal, bahkan sebelum ia dapat mengeluarkan ujaran. Seperti permainan cilukbaa (peek a boo) yang disukai Ameera dan disambut dengan senyum atau tawa merupakan bukti adanya kemampuan pragmatik anak pada awal hidupnya.

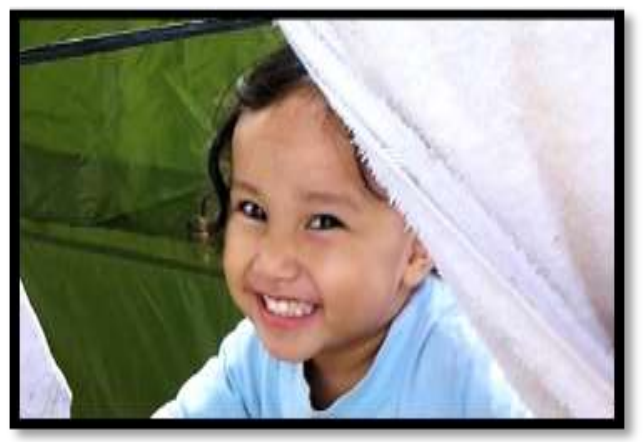

Gambar 4 Ameera bermain Peek a Boo (Video tanggal 31 Desember 2012)

Pada saat Ameera berusia 3 tahun kemampuan pengungkapan berbahasanya telah semakin baik. Kalimat yang sebelumnya hanya berupa penggalan, atau terdiri dari satu atau dua kata saja, seperti "matan" 'makan', "amina minum" 'ameera minum' menjadi lebih lengkap dan tersusun dengan benar seperti "atu mau matan ayam toreng" 'aku mau makan ayam goreng', "amina mau mandi tama bibi" 'ameera mau mandi sama abi'.

\section{Pemerolehan \\ Kemampuan}

\section{Percakapan}

Percakapan dalam arti verbal satu arah, yakni dari ibu kepada anak sebenarnya sudah dimulai sejak dini, sejak dalam kandungan dan saat anak mulai dilahirkan. Pada umur yang sangat muda ini, keluarga terdekat, lingkungan dan orang dewasa lainnya, sebenarnya sudah banyak berbicara kepada anak. Contohnya saja, seorang ibu 
yang memperlakukan anaknya yang berusia 3 bulan sebagai partisipan dalam suatu percakapan, namun tentu saja respon anak masih non-vokal dalam bentuk senyuman atau ocehan.

Berdasarkan pengalaman, sebenarnya secara alamiah, orangtua maupun lingkungan sekitar sudah mengajak "berbicara" kepada bayi yang baru berumur beberapa hari. Misalnya, ketika bayi menangis, ibu akan berkata, "kenapa sayang? Haus ya? Mau ibu beri susu?". Dengan kata lain sejak dilahirkan bahkan sejak dalam kandungan anak sudah terekpos kepada percakapan.

Percakapan bukanlah suatu wacana yang tanpa aturan. Percakapan mempunyai struktur: dimulai dengan pembukaan oleh salah satu pembicaranya, diikuti oleh giliran bicara para partisipan, dan kemudian diakhiri dengan penutup. Bisa saja ada masalah dalam struktur percakapan ini karena aturan ini tidak selalu diikuti sepenuhnya. Pada pembukaan misalnya, normanya adalah A membuka (selamat pagi) dan B merespon (selamat pagi). Akan tetapi, bisa saja respon tersebut tidak muncul disebabkan karena (1) B tidak mendengarnya; (2) B sedang marah kepada A; atau (3) ada sebab lainnya. Dalam hal ini percakapan tersebut mungkin tidak akan berlanjut (Dardjowidjojo, 2012: 281).

Pada anak, pembukaan suatu percakapan tidak selalu lancar dan

286 | Jurnal Kredo Vol. 2 No. 2 April 2019 lengkap. Jika diterapkan aturan percakapan ini pada anak-anak usia Ameera (dan pada kebanyakan anak lainnya) saat usia sekitar 2 tahun, seringkali untuk membuka suatu percakapan dan mendapatkan respon, perlu dilakukan lebih dari satu kali. Pengulangan tersebut seringkali terjadi pada Ameera, khususnya saat di usianya 2 tahun.

(a) Ameera mau coklat? Iya? Ameera mau coklat?

(b) Ameera, Ameera, bebek mana bebek? bebek mana? (Rekaman Video 15 Febuari 2012)

Hal tersebut terjadi karena beberapa hal, di antaranya adalah bahwa anak saat itu sedang sibuk (dengan dirinya sendiri), atau sedang melakukan sesuatu sehingga tidak mendengar yang mengajak bicara, atau anak tersebut sedang tidak ingin diganggu. Karena itu, dalam pembukaan seringkali nama mereka perlu dipanggil bahkan mungkin lebih dari satu kali.

Hal ini berubah sesuai dengan perkembangan usia Ameera. Pada usia 3 tahun sapaan pembukaan sudah tidak perlu diulang. Begitu pula dalam hal giliran bicara, tampak bahwa Ameera telah menguasai aturanaturan percakapan yang layaknya diikuti, seperti ia menanggapi saat gilirannya tiba, menunggu respon dari ilokutornya, kemudian menanggapinya kembali. 


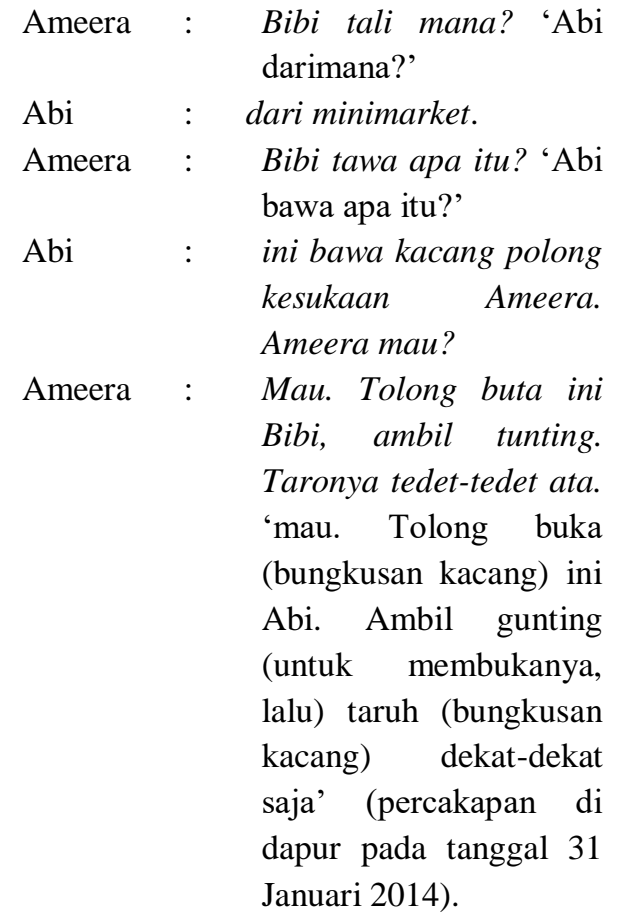

Dari percakapan di atas telah tampak bahwa aturan mengenai giliran bicara telah dikuasai dengan baik. Pasangan kalimat serasi antara satu pembicara dengan pembicara lain juga sudah mulai tampak runtun. Kalimat "Bibi tali mana?" 'Abi darimana?' dan "Bibi tawa apa itu?" 'Abi bawa apa itu?' merupakan ilokusi yang membutuhkan jawaban (requesting answer). Pada mulanya, di usia Ameera 1-2 tahun, bentuk ilokusi ini hadir belum dalam kalimat tetapi mungkin berupa gerakan tubuh (gesture), ocehan atau potongan kata. Dalam perkembangannya saat Ameera berusia 3 tahun, ilokusi telah hadir dalam sebuah kalimat yang jelas. Meskipun secara fonologis masih belum sempurna. Pada kalimat "Mau. Tolong buta ini Bibi, ambil tunting. Taronya tedet-tedet ata" "mau. Tolong buka (bungkusan kacang) ini Abi. Ambil gunting (untuk membukanya, lalu) taruh (bungkusan kacang) dekat-dekat saja' mengindikasikan bahwa penggunaan tindak tutur direktif atau yang disebut juga dengan tindak tutur impositif telah digunakan oleh Ameera sebagai ilokusi yang membutuhkan aksi (requesting action) dari Ayahnya dalam hal ini membukakan bungkusan kacang polong dan meletakkannya dalam jangkauan Ameera.

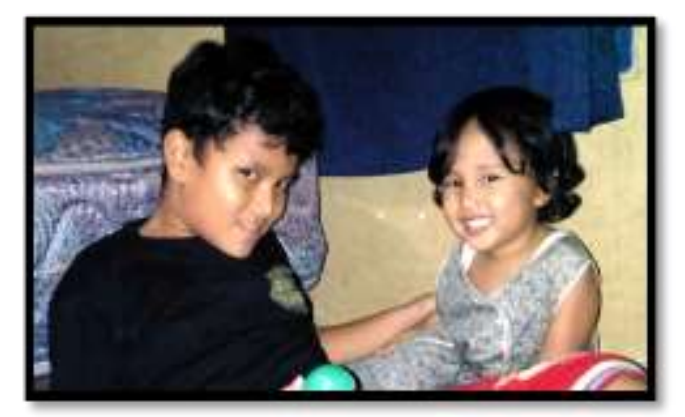

\section{Gambar 5 Ameera sedang}

\section{Bermain bersama Kakak Adam Pemerolehan Piranti Wacana}

Hampir semua wacana Ameera berbentuk dialog. Wacana dalam bentuk monolog lebih sering muncul saat Ameera telah berusia 3 tahun ke atas, misalnya saat ia bermain sendiri atau sedang menyenandungkan lagu sambil bercerita sendiri. Akan tetapi, bisa saja bahwa monolog yang terlihat ketika Ameera bermain boneka sesungguhnya ia sedang bermain peran dan melakukan dialog antar boneka atau antara dirinya dengan boneka. Karena menurut Owens, ujaran anak yang berbentuk monolog hanya sekitar 20 s.d. $30 \%$. 
Perbedaan struktur monolog
dan dialog terdapat dalam keduanya. Pada struktur dialog, kedua pembicara berbagi latar belakan pengetahuan, satu memberikan masukan kepada yang lain. Kedua partisipan bertindak secara aktif. Arah pembicaraan juga dipengaruhi oleh masukan timbal balik dari kedua interlokutor. Sedangkan pada monolog, pendengar tidak bertindak aktif. Karena itu pembicara harus mengorganisir dan memberikan informasi dalam suatu kesatuan yang utuh. Sehingga pada umumnya monolog berbentuk naratif, dan biasanya pula dikuasai belakangan.

Abi : Ameera, Bunda di mana?

Ameera : Lagi shusu Yahnek 'lagi memberi susu kepada Yahnek'

Ameera : Ini paddle? 'ini Puzzle?' I lop bobi bobi bobi 'Ameera bersenandung: I love to move it, move it'

Abi : Ameera, Bunda ada di mana?

Ameera : Ada di tamar 'ada di kamar'

Abi : Di kamar siapa?

Ameera : Yahnek, duduk, bunda aku duduk (Rekaman video percakapan di kamar pada tanggal 30 Desember 2013).

Pertambahan umur membuat Ameera semakin mampu meramu kalimat. Dalam membuat pertanyaan maupun menjawab pertanyaan secara koheren. Kalimat "Lagi shusu Yahnek" 'lagi memberi susu kepada Yahnek', "Ada di tamar" 'ada di kamar', dan
"Yahnek, duduk, bunda aku duduk". Merupakan tindak tutur representatif (melaporkan) dalam rangka menjawab pertanyaan yang diajukan mengenai keberadaan sang Bunda. Di sini Ameera telah terlihat dapat berada dalam suatu wacana dialog dengan memberikan respon yang relevan.

\section{SIMPULAN}

Berdasarkan temuan dalam penelitian ini dapat disimpulkan bahwa di usia 0 s.d 1 tahun, tindak tutur baik lokusi, ilokusi maupun perlokusi dalam bentuk kalimat atau kata belum tampak pada anak karena anak memang belum memiliki tabungan kosa kata yang cukup untuk berkomunikasi. Dalam memberikan informasi tentang kondisinya diungkapkan dengan senyuman dan tangisan saja. Kemudian pada usia selanjutnya, di atas 1 tahun, ketika kosa kata yang dimilikinya telah cukup, anak mulai menggunakan kata atau potongan kata dalam tindak tutur lokusi, ilokusi dan perlokusinya. Selanjutnya, ketika usia anak telah mencapai 3 tahun ke atas, kalimat yang lebih lengkap mulai digunakan dalam tindak tuturnya.

Perkembangan pragmatik seorang anak sesungguhnya telah terjadi sejak dalam kandungan dan hari pertama kelahirannya. Secara bertahap kemampuan seorang anak akan berkembang seiring dengan kebutuhannya akan komunikasi 
dengan orang-orang sekitar dan lingkungannya. Begitu pula dalam percakapan. Aturan percakapan mulai terbentuk saat anak berusia tiga tahun. Sedangkan dibawah usia tersebut aturan percakapan belumlah sesuai dengan kaidah yang ada. Sedangkan dalam pengembangan wacana, pada umumnya anak-anak lebih dominan dalam bentuk wacana dialog. Keuntungan dari bentuk wacana dialog adalah adanya saling berbagi pengetahuan antar ilukator. Hal tersebut menambah khazanah ilmu pengetahuan ataupun kebahasaan bagi anak.

\section{DAFTAR PUSTAKA}

Tarigan, Henry Guntur. 1986. Pengajaran Pragmatik. Bandung: Penerbit Angkasa.

Kridalaksana, Harimurti. 1984. Kamus Linguistik. Jakarta: Gramedia.

Dardjowidjojo, Soenjono. 2000. Echa: Kisah Pemerolehan Bahasa Anak Indonesia. Jakarta: Gramedia.

Dardjowidjojo, Soenjono. 2012. Psikolinguistik: Pengantar Pemahaman Bahasa Manusia, Edisi Kedua. Jakarta: Unika Atma Jaya, Pustaka Obor Indonesia.

Ninio, Anat., Snow, Catherine E. 1996. Pragmatic Development. Boulder Colorado: Westview Press.

DeLamater, John. 2003. Handbook of Social Psychology. New York: Kluwer Academic; Plenum Publishers.

Walcott., William H. 2007. Knowledge, Competence and Communication: Chomsky, Freire, Searle, and Communicative Language Teaching. Canada: Black Rose Books Ltd.

Searle, John R. 1969. Speach Act: An Essay in the Philoshopy of Language. United Kongdom: Cambridge University.

Austin, John. L. 1962. How To Do Things with Words. London: Oxford University Press.

Leech, Geoffrey. 1993. Prinsip-prinsip Pragmatik. Jakarta: Universitas Indonesia. 
Brown, James Dean. Research Methods for Applied Linguistics; Scope, Characteristics, and Standards.

Davies, Alan dan Elder, Catherine (ed). 2004. The Handbook of Applied Linguistics. Malden/Oxford/Victoria: Blackwell Publishing.

Guba, and Lincoln. Naturalistic Inquiry. Beverly Hills, CA: Sage Publications, Inc.

Hoepfl, Marie C. 1997. Choosing Qualitative Research: A Primer for Technology Education Researchers dalam Journal of Technology Education, Volume 9: Number 1

Faridah, Siti. 2017. Fungsi Pragmatis Tuturan Humor Madihin Banjar, Jurnal KREDO: Jurnal Ilmiah Bahasa dan Sastra, Vol 1, No 1. DOI: $\underline{\text { https://doi.org/10.24176/kredo.v1i1.1755. }}$.

Wardhani, Pramika. 2018. Wujud Pilihan Bahasa dalam Ranah Keluarga Pada Masyarakat Perumahan di Kota Purbalingga, Jurnal KREDO: Jurnal Ilmiah Bahasa dan Sastra, Vol 1, No 2. DOI: https://doi.org/10.24176/kredo.v1i2.2147. 